\title{
Efek Suplementasi Omega 3 dan Latihan Fisik Terhadap Respon Inflamasi
}

Novadri Ayubia , Bambang Purwanto ${ }^{b}$, Purwo Sri Rejekic

abcUniversitas Airlangga, Indonesia

Correspondence: bpaifo@gmail.com

Received: 23 Jul 2020 Accepted: 10 Oct 2020 Published: 31 Oct 2020

\begin{abstract}
The aims of this article is to find out how the effects of omega 3 supplementation and physical exercise on the inflammatory response. The method applied is literature review. The results showed that omega 3 supplementation and regular exercise can reduce the inflammatory response that is not controlled. Inflammation is a protective response caused by injury or tissue damage. After physical exercise the body will experienced an increase in inflammatory markers, namely CRP, IL-1, IL-6, IL-10 and TNF- $\alpha$. Physical exercise, especially high-intensity eccentric exercises, will cause damage to muscle fibers and delayed muscle pain (DOMS) which results in disruption to muscle strength. Muscle pain is caused by an inflammatory process due to increased levels TNF- $\alpha$ in response to muscle damage. Inflammatory response that is not controlled can be controlled by giving omega 3 supplementation. It can be concluded that omega 3 supplementation and regular exercise are proven to reduce the inflammatory response that is not controlled, so to reduce the intensity of pain and support the performance in carrying out the physical exercise program.
\end{abstract}

Keywords: omega 3; exercise; inflammation

\begin{abstract}
Abstrak
Penulisan artikel ini bertujuan untuk mengetahui bagaimana pengaruh suplementasi omega 3 dan latihan fisik terhadap respon inflamasi. Metode yang digunakan adalah literatur review. Hasil penelitian menunjukan bahwa suplementasi omega 3 dan latihan teratur dapat menurunkan respon inflamasi yang tidak terkontrol. Inflamasi merupakan respons protektif yang ditimbulkan oleh cedera atau kerusakan jaringan. Setelah melakukan latihan fisik tubuh akan mengalami peningkatan indikator inflamasi yaitu CRP, IL-1, IL-6, IL-10 dan TNF- $\alpha$. Latihan fisik terutama latihan eksentrik dengan intensitas tinggi akan menyebabkan kerusakan serat otot dan nyeri otot yang tertunda (DOMS), sehingga mengakibatkan gangguan terhadap kekuatan otot. Nyeri otot disebabkan oleh proses inflamasi karena peningkatan kadar TNF- $\alpha$ sebagai respon kerusakan otot. Respon inflamasi yang tidak terkontrol dapat dikendalikan oleh pemberian suplementasi omega 3. Dapat disimpulkan bahwa suplementasi omega 3 dan latihan teratur terbukti dapat menurunkan respon inflamasi yang tidak terkontrol, sehingga dapat menurunkan intensitas nyeri dan menunjang performa dalam menjalankan program latihan fisik.
\end{abstract}

Kata kunci: omega 3; latihan fisik; inflamasi

\section{Pendahuluan}

Latihan eksentrik dengan intensitas tinggi akan menyebabkan kerusakan serat otot dan nyeri otot yang tertunda (DOMS) yang mengakibatkan gangguan terhadap kekuatan otot (Hedayatpour et al., 
2018). Secara umum DOMS akan terjadi antara 24-48 jam pasca latihan (Kim et al., 2017). Latihan eksentrik merupakan latihan yang membutuhkan kontraksi otot memanjang dan memendek secara kuat (Couppé et al., 2015; Stasinopoulos and Stasinopoulos, 2017). Latihan eksentrik mengarah pada timbulnya respons inflamasi yang terkait dengan penurunan kemampuan kekuatan otot, penurunan rentang gerak, dan nyeri otot (Fatouros and Jamurtas, 2016). Latihan eksentrik meningkatkan penanda inflamasi yaitu C-Reaktive Protein (CRP), Interlenkin 1 (IL-1), Interlenkin 6 (IL-6), Interlenkin 10 (IL-10) dan Tumor Necrosis Factor- $\alpha$ (TNF- $\alpha$ ) (Sciberras et al., 2015). Respon inflamasi yang tidak terkontrol dapat menyebabkan tidak maksimalnya proses latihan yang dilakukan. Selain latihan eksentrik, latihan aerobik seperti marathon juga dapat menyebabkan kerusakan otot dan respon inflamasi akut, namun juga dapat meningkatkan sitokin anti-inflamasi (Mach and Fuster-Botella, 2017).

Inflamasi merupakan respons protektif yang ditimbulkan oleh cedera atau kerusakan jaringan yang disebabkan oleh trauma fisik, zat kimia yang merusak atau zat mikrobiologik (Turkmen and Yazar, 2017). Inflamasi berfungsi untuk menghancurkan dan mengurangi agen yang merusak maupun jaringan yang rusak (Agustina et al., 2015). Pada tingkat jaringan, inflamasi ditandai dengan kemerahan, pembengkakan, panas, nyeri, dan hilangnya fungsi jaringan (Bahrudin, 2018).

Nyeri otot pasca latihan fisik menurut US Departement of Labor Bureau of Labor Statistic memiliki angka kejadian sebesar 76,5\% (Syarli and Pati, 2017). Selama ini banyak dari orang yang terlibat dalam aktivitas fisik yang tinggi menggunakan obat anti inflamasi non steroid dalam pengelolaan nyeri yang nanti nya akan berdampak kepada kesehatan dan program latihan (Harle et al., 2018; Tamarat et al., 2018). Selain menggunakan obat anti inflamasi non steroid, sebagian besar orang sangat lazim melakukan terapi massage untuk mengurangi nyeri (Furlan et al., 2015; Lee et al., 2015; Poppendieck et al., 2016).

Alternatif solusi lain perlu dicari untuk mengatasi masalah tersebut, salah satu cara meminimalkan respon inflamasi yang tidak terkontrol dengan menggunakan produk alami yang berasal dari minyak ikan yaitu senyawa omega 3. Omega 3 merupakan asam lemak tak jenuh (Polyunsaturated Fatty Acids) yang terdiri dari beberapa ikatan rangkap (Durán et al., 2019). Kandungan utama pada omega 3 yaitu $\alpha$-linolenat, (ALA), asam eikosapentaenoat (EPA), dan asam docosahexaenoic (DHA) (Baker et al., 2016). Omega 3 terkenal dengan kandungan anti inflamasi (Gammone et al., 2019). Suplementasi omega 3 juga ditunjukkan untuk mengurangi nyeri dan mempertahankan fungsi otot setelah kerusakan otot akibat latihan eksentrik (Black et al., 2018). Omega-3 memengaruhi respons imun, sebagian dengan memengaruhi sekresi sitokin dengan menurunkan sekresi TNF- $\alpha$ (Morin $e t$ al., 2017).

Penelitian ini bertujuan untuk mengetahui efek suplementasi omega 3 dan latihan fisik terhadap respon inflamasi. Hasil penelitian ini di diharapkan bisa menjadi acuan bagaimana cara mengatasi respon inflamasi yang tidak terkontrol sehingga latihan yang dilakukan dapat maksimal.

\section{Metode Penelitian}

Penelitian ini menggunakan metode literature review dengan menggunakan strategi secara komprehensif seperti pencarian artikel dalam database jurnal penelitian, pencarian melalui internet, tinjauan ulang artikel. Pencarian database data yang digunakan yaitu Proquest, Pubmed, sciencediretct.com, elsevier jurnal. Kriteria inklusi dalam penelitian ini yaitu jurnal berbahasa Indonesia dan Inggris yang membahas tentang fisiologi olahraga, omega 3, latihan fisik, nyeri otot yang tertunda (DOMS), dan inflamasi. Kriteria eksklusi dalam penelitian ini yaitu jurnal nasional dan internasional yang telah diterbitkan lewat dari 5 tahun terakhir ditahun 2020. Kata kunci yang digunakan dalam pencarian artikel yaitu omega 3, exercise, inflammation. Terdapat 32 artikel yang diperoleh dan 10 artikel dianalisis 
melalui analisis tujuan, kesesuaian topik, ukuran sampel, protokol penelitian dan hasil dari setiap artikel.

\section{Hasil}

Adapun hasil dari penelitian yang digunakan dalam literature review ini sebagai berikut:

\section{Tabel 1. Review Hasil Penelitian}

\begin{tabular}{|c|c|c|c|}
\hline Author & Sampel & Protokol & Hasil \\
\hline $\begin{array}{l}\text { (Zheng et al., } \\
\text { 2019) }\end{array}$ & $\begin{array}{l}\text { Sebelas penelitian yang melibatkan } \\
1250 \text { peserta diambil dari database } \\
\text { untuk dianalisis. Pencarian literatur } \\
\text { dilakukan dengan menggunakan } \\
\text { PubMed, Web of Science, Embase, dan } \\
\text { perpustakaan Cocharane dari awal } \\
\text { hingga April } 2018 \text {. }\end{array}$ & $\begin{array}{l}\text { Latihan } \\
\text { aerobik }\end{array}$ & $\begin{array}{l}\text { Latihan aerobik secara teratur } \\
\text { dapat mengurangi penanda } \\
\text { inflamasi C-reaktive Protein } \\
\text { (CRP), Tumor Necrosis Factor } \\
\text { alpha (TNF- } \alpha \text { ), dan } \\
\text { Interlenkin-6 (IL-6)). }\end{array}$ \\
\hline $\begin{array}{l}\text { (Gutiérrez-Pliego } \\
\text { et al., 2018) }\end{array}$ & $\begin{array}{l}\text { Subjek } 68 \text { tikus jantan berusia } 8 \\
\text { minggu di bagi menjadi } 2 \\
\text { kelompok yaitu kelompok } \\
\text { perlakuan dan kelompok kontrol. } \\
\text { Perlakuan dilakukan dari minggu } \\
\text { ke } 8 \text { hingga ke } 16 \text { kehidupan }\end{array}$ & $\begin{array}{l}\text { Suplementasi } \\
\text { omega } 3\end{array}$ & $\begin{array}{l}\text { Suplementasi omega } 3 \text { dapat } \\
\text { menurunkan Tumor Necrosis } \\
\text { Factor Alpha }(\text { TNF- } \alpha) \text {. }\end{array}$ \\
\hline $\begin{array}{l}\text { (Corder et al., } \\
\text { 2016) }\end{array}$ & $\begin{array}{l}27 \text { wanita sehat di bagi menjadi } 2 \\
\text { kelompok yaitu kelompok } \\
\text { perlakuan dan kelompok kontrol. } \\
\text { Perlakuan dilakukan selama } 7 \text { hari }\end{array}$ & $\begin{array}{l}\text { Latihan } \\
\text { eksentrik } \\
\text { intensitas } \\
\text { tinggi dan } \\
\text { omega } 3\end{array}$ & $\begin{array}{l}\text { Suplementasi omega } 3 \text { dapat } \\
\text { mengurangi intensitas nyeri } \\
\text { dan meningkatkan kekuatan } \\
\text { otot. }\end{array}$ \\
\hline $\begin{array}{l}\text { (Durán et al., } \\
\text { 2019) }\end{array}$ & $\begin{array}{l}40 \text { relawan dengan diabetes type } 2 \\
\text { diberikan intervensi omega } 3 \\
\text { selama } 3 \text { bulan. Penelitian ini } \\
\text { menilai gejala nyeri yang } \\
\text { dilaporkan sendiri sebelum dan } \\
\text { sesudah diberi intervensi. }\end{array}$ & $\begin{array}{l}\text { Suplementasi } \\
\text { omega } 3\end{array}$ & $\begin{array}{l}\text { Suplementasi omega } 3 \text { dapat } \\
\text { mengurangi intensitas nyeri } \\
\text { pada individu dengan diabetes } \\
\text { tipe } 2 \text {. }\end{array}$ \\
\hline$\overline{\text { (Smith } \text { et al., 2015) }}$ & $\begin{array}{l}60 \text { pria dan wanita secara acak } \\
\text { dibagi menjadi } 2 \text { kelompok, yaitu } \\
\text { kelompok yang diberikan omega } 3 \\
\text { dan minyak jagung selama } 6 \text { bulan }\end{array}$ & $\begin{array}{l}\text { Suplementasi } \\
\text { omega } 3\end{array}$ & $\begin{array}{l}\text { Pemberian suplementasi } \\
\text { omega } 3 \text { dapat meningkatkan } \\
\text { kekuatan otot karena } \\
\text { peningkatan kualitas otot dan } \\
\text { hipertrofi otot. }\end{array}$ \\
\hline (Coghill et al., 2018) & $\begin{array}{l}.60 \text { pria dan wanita secara acak } \\
\text { dibagi menjadi } 2 \text { kelompok yaitu } \\
\text { kelompok yang diberikan omega } 3 \\
\text { dengan dosis } 3 \text { gram dan } \\
\text { kelompok yang diberikan placebo } \\
\text { selama } 12 \text { minggu }\end{array}$ & $\begin{array}{l}\text { Suplementasi } \\
\text { omega } 3\end{array}$ & $\begin{array}{l}\text { Suplementasi omega } 3 \text { dapat } \\
\text { menurunkan Interlenkin-6 (IL- } \\
\text { 6) }\end{array}$ \\
\hline $\begin{array}{l}\text { (Sawada et al., } \\
\text { 2016) }\end{array}$ & $\begin{array}{l}107 \text { pasien gangguan metabolism } \\
\text { glukosa secara acak dibagi menjadi } \\
2 \text { kelompok yaitu kelompok yang } \\
\text { diberikan omega } 3 \text { dan kelompok } \\
\text { tanpa omega } 3 \text { selama } 6 \text { bulan. }\end{array}$ & Omega 3 & $\begin{array}{l}\text { Omega } 3 \text { dapat menurunkan } \\
\text { C-Reaktive Protein (CRP) }\end{array}$ \\
\hline
\end{tabular}




\section{Pembahasan}

Inflamasi merupakan respons protektif ditimbulkan oleh cedera atau kerusakan jaringan yang disebabkan oleh trauma fisik, zat kimia yang merusak, atau zat mikrobiologik (Agustina et al., 2015). Inflamasi berfungsi untuk menghancurkan, mengurangi, atau melokalisasi (sekuster) baik agen yang merusak maupun jaringan yang rusak (Dewanto, 2017). Sebagai respons terhadap cedera jaringan, tubuh memulai kaskade pensinyalan kimiawi yang merangsang respons yang bertujuan menyembuhkan jaringan yang cedera. Sinyal-sinyal ini mengaktifkan kemotaksis leukosit dari sirkulasi umum ke tempat-tempat kerusakan. Leukosit yang teraktivasi ini menghasilkan sitokin yang menginduksi respon inflamasi (McMahon et al., 2019).

Setelah melakukan latihan fisik tubuh akan meningkatkan penanda inflamasi yaitu CRP, IL-1, IL-6, IL-10 dan TNF- $\alpha$ (Sciberras et al., 2015). Latihan fisik terutama latihan eksentrik dengan intensitas tinggi akan menyebabkan kerusakan serat otot dan nyeri otot yang tertunda (DOMS) yang mengakibatkan gangguan terhadap kekuatan otot (Hedayatpour, Izanloo and Falla, 2018). Nyeri otot disebabkan oleh proses inflamasi karena peningkatan kadar TNF- $\alpha$ sebagai respon kerusakan otot (Kim et al., 2017).

Beberapa upaya untuk mengurangi respon inflamasi yang tidak terkontrol yaitu dengan melakukan latihan secara teratur, pada penelitian (Zheng et al., 2019) menjelaskan bahwa latihan aerobik secara teratur dapat mengurangi penanda inflamasi yaitu CRP, IL-6 dan TNF- $\alpha$. Selain itu upaya untuk mengurangi respon inflamasi yang tidak terkontrol dengan menggunakan suplementasi omega 3. Omega 3 terkenal dengan anti inflamasinya (Khan, 2017). Kandungan utama pada omega 3 yaitu asam $\alpha$-linolenat (ALA), asam eikosapentaenoat (EPA), dan asam docosahexaenoic (DHA) (Baker et al., 2016; Endo and Arita, 2016). Omega 3 dapat menghambat inflamasi melalui blokade sinyal TNF$\alpha$ dengan mengaktifkan respon protein pada otot (Khan, 2017). Dibuktikan dengan penelitian (Gutiérrez-Pliego et al., 2018) menjelaskan bahwa pemberian suplementasi omega 3 dapat menurunkan kadar TNF- $\alpha$. Dalam penelitian (Coghill et al., 2018) Omega 3 dibuktikan dapat menurunkan penanda inflamasi yaitu IL-6 dan CRP (Sawada et al., 2016). Omega 3 otomatis akan mengurangi nyeri karena berperan dalam proses inflamasi yang tidak terkontrol. Dibuktikan juga dalam penelitian (Corder et al., 2016) menjelaskan bahwa suplementasi dapat mengurangi intensitas nyeri dan meningkatkan kekuatan otot.

Untuk lebih jelasnya, berikut ini mekanisme kerja omega 3 dalam proses inflamasi:

Selama respons inflamasi akut, kejadian interaksi seluler dan molekuler secara efisien meminimalkan cedera atau infeksi yang akan terjadi. Proses ini berkontribusi pada pemulihan homeostasis jaringan dan resolusi peradangan akut. Namun, peradangan akut yang tidak terkontrol dapat menjadi kronis dan berkontribusi terhadap berbagai penyakit radang kronis (Zhou, Hong and Huang, 2016). Mekanisme yang memungkinkan asam lemak omega-3 meningkatkan miogenesis (Bhullar et al., 2016). Salah satu jalur melibatkan Peroxisome proliferator-activated receptors (PPAR), dimana merupakan kelompok reseptor nuklir yang memiliki karakteristik untuk mencegah gangguan metabolisme, mendorong adaptasi pada otot rangka setelah latihan fisik, dan memiliki peran baru dalam mengatur sel satelit (Deng et al., 2016).

PPAR merupakan regulator penting dari gen yang terlibat dalam perkembangan, metabolisme lemak dan karbohidrat, serta peradangan. Bukti terbaru menunjukkan omega 3, mampu mengikat PPAR yang mendorong aktivasi dan mengubah ekspresi gen pro-inflamasi (Fritsche, 2015). Selanjutnya omega-3 menghambat aktivasi Nuclear Factor- kB (NF-kB) dan mengurangi pelepasan sitokin dan 
protein inflamasi, termasuk IL-6 dan TNF- $\alpha$. Dalam proses inflamasi pada otot rangka dihubungkan secara timbal balik. Penurunan protein inflamasi meningkatkan proliferasi dan diferensiasi sel-sel satelit (Bhullar et al., 2016).

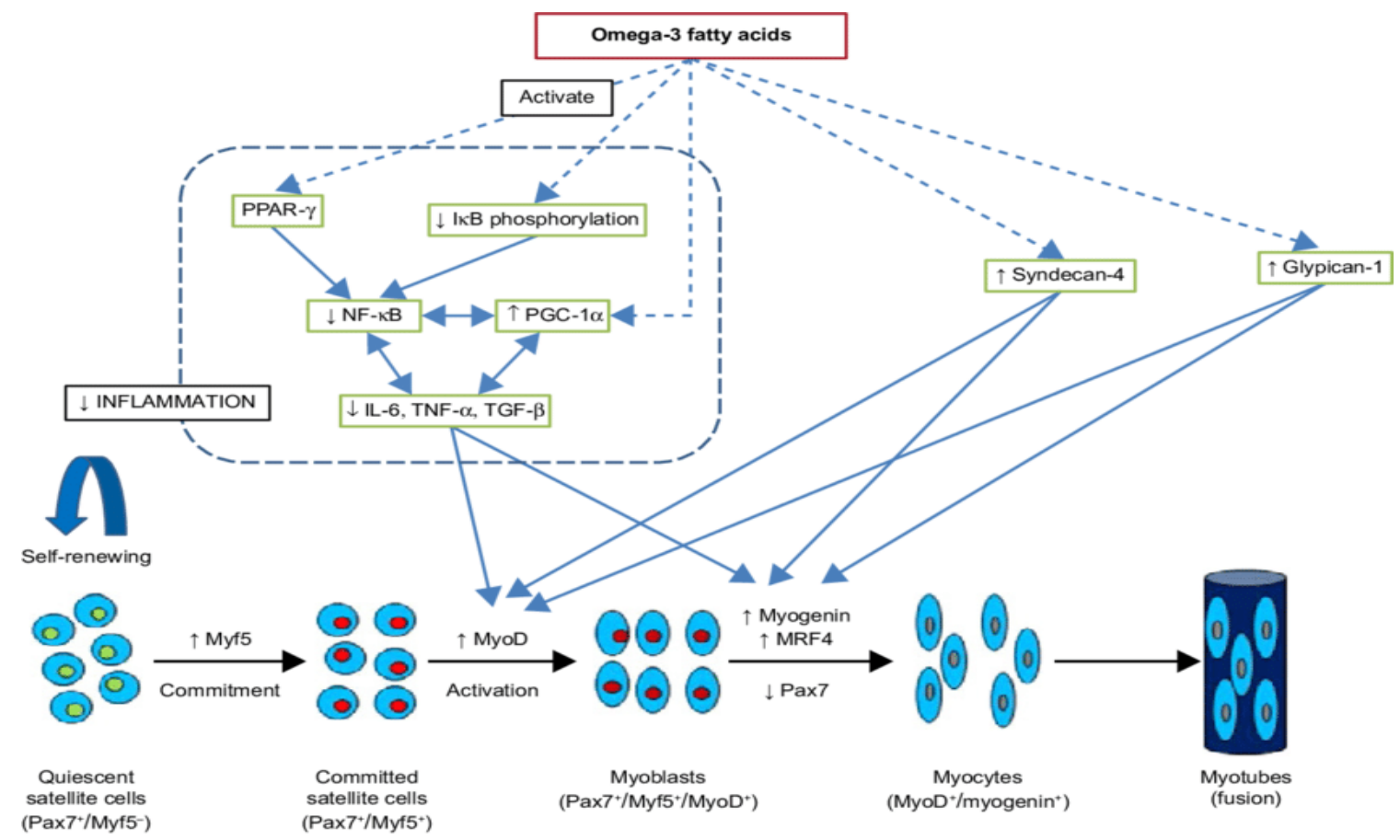

Gambar 1. Mekanisme Kerja Omega 3 Dalam Proses Inflamasi (Bhullar et al., 2016)

\section{Simpulan dan Rekomendasi}

Suplementasi omega 3 dan latihan teratur terbukti dapat mengurangi respon inflamasi yang tidak terkontrol dengan menurunkan penanda inflamasi yaitu CRP, IL-1, IL-6, IL-10 dan TNF- $\alpha$ sehingga dapat menurunkan intensitas nyeri yang kemudian akan menunjang peforma dalam menjalankan program latihan terutama latihan untuk meningkatkan kekuatan otot.

Pasca latihan eksentrik dengan intensitas tinggi sangat direkomendasikan untuk mengkonsumsi suplementasi omega 3. Di samping menggunakan terapi massage, konsumsi omega 3 secara teori mampu menurunkan intensitas nyeri sehingga hasil latihan bisa didapatkan dengan maksimal.

\section{Daftar Pustaka:}

Agustina, R., Indrawati, D. T. and Masruhim, M.A. (2015). Aktivitas Ekstrak Daun Salam (Eugenia Polyantha) Sebagai Antiinflamasi Pada Tikus Putih (Rattus Norvegicus). Journal Of Tropical Pharmacy And Chemistry. 3(2): 120-123. https://doi.org/10.25026/itpc.v3i2.96.

Bahrudin, M. (2018) 'Patofisiologi Nyeri (Pain). Saintika Medika. 13(1): 7-13. https://doi.org/10.22219/sm.v13i1.5449.

Baker, E.J., Miles, E.A., Burdge, G.C., Yaqoob, P. and Calder, P.C. (2016). Metabolism and functional effects of plant-derived omega-3 fatty acids in humans. Progress in Lipid Research. 64:30-56. https://doi.org/10.1016/j.plipres.2016.07.002. 
Bhullar, A.S., Putman, C.T. and Mazurak, V.C. (2016). Potential Role of Omega-3 Fatty Acids on the Myogenic Program of Satellite Cells. Nutrition and Metabolic Insights. 9: 1-10. https://doi.org/10.4137/nmi.s27481.

Black, K. E., Witard, O. C., Baker, D., Healey, P., Lewis, V., Tavares, F., Christensen, S., Pease, T. and Smith, B. (2018). Adding omega-3 fatty acids to a protein-based supplement during preseason training results in reduced muscle soreness and the better maintenance of explosive power in professional Rugby Union players. European Journal of Sport Science. 18(10): 1357-1367. https://doi.org/10.1080/17461391.2018.1491626

Coghill, A. E., Schenk, J. M., Mahkoul, Z., Orem, J., Phipps, W. and Casper, C. (2018) 'Omega-3 decreases IL-6 levels in HIV and human herpesvirus-8 coinfected patients in Uganda', AIDS. https://doi.org/ 10.1097/ QAD.0000000000001722

Corder, K. E., Newsham, K. R., McDaniel, J. L., Ezekiel, U. R. and Weiss, E. P. (2016) 'Effects of short-term docosahexaenoic acid supplementation on markers of inflammation after eccentric strength exercise in women', Journal of Sports Science and Medicine.

Couppé, C., Svensson, R.B., Silbernagel, K.G., Langberg, H. and Magnusson, S.P. (2015). Eccentric or concentric exercises for the treatment of tendinopathies?. Journal of Orthopaedic and Sports Physical Therapy. 45(11):853-863. https://doi.org/10.2519/jospt.2015.5910.

Deng, B., Zhang, F., Chen, K., Wen, J., Huang, H., Liu, W., Ye, S., Wang, L., Yang, Y., Gong, P. and Jiang, S. (2016) 'MyoD promotes porcine PPAR $\gamma$ gene expression through an E-box and a MyoD-binding site in the PPAR $\gamma$ promoter region', Cell and Tissue Research. https://doi.org/ 10.1007/s00441-016-2380-3

Durán, A. M., Salto, L. M., Câmara, J., Basu, A., Paquien, I., Beeson, W. L., Firek, A., CorderoMacintyre, Z. and De León, M. (2019). Effects of omega-3 polyunsaturated fatty-acid supplementation on neuropathic pain symptoms and sphingosine levels in Mexican-Americans with type 2 diabetes. Diabetes, Metabolic Syndrome and Obesity: Targets and Therapy. 2019 (12): 109120. https://doi.org/10.2147/DMSO.S187268.

Endo, J. and Arita, M. (2016). Cardioprotective mechanism of omega-3 polyunsaturated fatty acids. Journal of Cardiology. 67(1): 22-27. https://doi.org/10.1016/j.jacc.2015.08.002.

Fatouros, I. G. and Jamurtas, A. Z. (2016). Insights into the molecular etiology of exercise-induced inflammation: Opportunities for optimizing performance. Journal of Inflammation Research. 9: 175-186. https://doi.org/10.2147/JIR.S114635.

Fritsche, K. L. (2015) 'The Science of Fatty Acids and Inflammation', Advances in Nutrition. https://doi.org/10.3945/an.114.006940

Furlan, A. D., Giraldo, M., Baskwill, A., Irvin, E. and Imamura, M. (2015). Massage for low-back pain. Cochrane Database of Systematic Reviews. (9): CD001929. https://doi.org/10.1002/14651858.CD001929.pub3.

Gammone, M. A., Riccioni, G., Parrinello, G. and D'orazio, N. (2019). Omega-3 polyunsaturated fatty acids: Benefits and endpoints in sport. Nutrients. 11(1): 46. https://doi.org/10.3390/nu11010046.

Gutiérrez-Pliego, L.E., Martínez-Carrillo, B.E., Reséndiz-Albor, A.A., Arciniega-Martínez, I.M., Escoto-Herrera, J.A., Rosales-Gómez, C.A. and Valdés-Ramos, R. (2018). Effect of 
Supplementation with $\mathrm{n}-3$ Fatty Acids Extracted from Microalgae on Inflammation Biomarkers from Two Different Strains of Mice. Journal of Lipids. 2018 (Article ID 4765358): 10 pages. https://doi.org/10.1155/2018/4765358.

Harle, C. A., Danielson, E. C., Derman, W., Stuart, M., Dvorak, J., Smith, L. and Hainline, B. (2018). Analgesic Management of Pain in Elite Athletes: A Systematic Review. Clinical journal of sport medicine: official journal of the Canadian Academy of Sport Medicine. 28(5): 417-426. https://doi.org/10.1097/JSM.0000000000000604.

Hedayatpour, N., Izanloo, Z. and Falla, D. (2018). The effect of eccentric exercise and delayed onset muscle soreness on the homologous muscle of the contralateral limb. Journal of Electromyography and Kinesiology. 41: 154-159. https://doi.org/10.1016/j.jelekin.2018.06.003.

Khan, S.A. (2017). Effects of Short Term Supplementation of Fish Oil Capsules on the Blood Fatty Acid Profile of Vegetarians : A Pilot Study. Int J Med Res Health Sci. 6(5): 19-23.

Kim, J., Kim, J. and Lee, J. (2017). Effect of compression garments on delayed-onset muscle soreness and blood inflammatory markers after eccentric exercise: A randomized controlled trial. Journal of Exercise Rebabilitation. 13(5): 541-545. https://doi.org/10.12965/jer.1735088.554.

Lee, S. H., Kim, J. Y., Yeo, S., Kim, S. H. and Lim, S. (2015). Meta-Analysis of Massage Therapy on Cancer Pain. Integrative Cancer Therapies. 14(4): 297-304. https://doi.org/10.1177/1534735415572885.

Mach, N. and Fuster-Botella, D. (2017). Endurance exercise and gut microbiota: A review', Journal of Sport and Health Science. 6(2): 179-197. https://doi.org/10.1016/j.jshs.2016.05.001.

McMahon, G., Morse, C. I., Winwood, K., Burden, A. and Onambélé, G. L. (2019). Circulating tumor necrosis factor alpha may modulate the short-term detraining induced muscle mass loss following prolonged resistance training. Frontiers in Physiology. 10(527): 1-11. https://doi.org/10.3389/fphys.2019.00527.

Morin, C., Charbonneau, L., Ouellet, N., Ouellet, H., Blier, P. U., Dufresne, F. and Fortin, S. (2017). Eicosapentaenoic acid monoglyceride resolves inflammation in an ex vivo model of human peripheral blood mononuclear cell. European Journal of Pharmacology. 807:205-211. https://doi.org/10.1016/j.ejphar.2017.05.018.

Poppendieck, W., Wegmann, M., Ferrauti, A., Kellmann, M., Pfeiffer, M. and Meyer, T. (2016). Massage and Performance Recovery: A Meta-Analytical Review. Sports Medicine. 46(2): 183-204. https://doi.org/10.1007/s40279-015-0420-x.

Sciberras, I.N., Galloway, D.R., Fenech, A., Grech, G., Farrugia, C., Duca, D. and Mifsud, J. (2015). The effect of turmeric (Curcumin) supplementation on cytokine and inflammatory marker responses following 2 hours of endurance cycling. Journal of the International Society of Sports Nutrition. 12(1): 5. https://doi.org/10.1186/s12970-014-0066-3.

Smith, G. I., Julliand, S., Reeds, D. N., Sinacore, D. R., Klein, S. and Mittendorfer, B. (2015). Fish oil-derived n-3 PUFA therapy increases muscle mass and function in healthy older adults. American Journal of Clinical Nutrition. 102(1): 115-122. https://doi.org/10.3945/ajcn.114.105833.

Stasinopoulos, D. and Stasinopoulos, I. (2017). Comparison of effects of eccentric training, eccentric-concentric training, and eccentric-concentric training combined with isometric 
contraction in the treatment of lateral elbow tendinopathy. Journal of Hand Therapy. 30(1): 1319. https://doi.org/10.1016/j.jht.2016.09.001.

Syarli, H. and Pattie. (2017). Pengaruh Recovery Aktif dan Pasif dalam Meringankan Gejala Delayed Onset Muscle Soreness (DOMS). Journal of Sport Science and Education (Jossae). 2(2): 38-41.

Tamara, S., Leatemia, D. and Masjhoer, D.H. (2018). Studi OAINS pada Kasus Osteoartritis di RSUD Abdul Wahab Samarinda. Jurnal Kedokteran Mulawarman, 4(1): 29-38.

Turkmen, S. and Yazar, M. (2017). Inflammatory biomarkers, oxidative and antioxidative status. Turkish Journal of Biochemistry.

Zheng, G., Qiu, P., Xia, R., Lin, H., Ye, B., Tao, J. and Chen, L. (2019). Effect of aerobic exercise on inflammatory markers in healthy middle-aged and older adults: A systematic review and meta-analysis of randomized controlled trials. Frontiers in Aging Neuroscience. 11:98. https://doi.org/10.3389/ fnagi.2019.00098

Zhou, Ying, Yan Hong, and Haihua Huang. 2016. "Triptolide Attenuates Inflammatory Response in Membranous Glomerulo-Nephritis Rat via Downregulation of NF-KB Signaling Pathway." Kidney and Blood Pressure Research. https://doi.org/10.1159/000452591 